\title{
BADGER BEHAVIOR AT ANTHROPOGENIC WATER SOURCES IN THE CHIHUAHUAN DESERT
}

\author{
Robert L. Harrison ${ }^{1}$
}

\begin{abstract}
AвSTRACT.-Anthropogenic water sources such as tanks and ponds for livestock and troughs for wildlife (guzzlers) have become ubiquitous features of arid landscapes. Many species of wildlife are attracted to guzzlers, but behavior at guzzlers and effects of guzzlers upon wildlife are often poorly understood. I recorded rates of drinking and visitation by American badgers (Taxidea taxus) at guzzlers in the northern Chihuahuan Desert by use of automatic cameras over a 2 -year period. Badgers visited guzzlers throughout the year, and visited primarily at night. Badgers averaged 1.87 visits per site-week and drank during only $58 \%$ of visits. The rate of visitation and the number of drinking episodes per guzzler per week increased in summer, which, in addition to having higher temperatures, is also mating season for badgers.

RESUMEN.-Las fuentes antropogénicas de agua, tales como los tanques y estanques para el ganado y abrevaderos para la fauna silvestre, se han convertido en características ubicuas de los paisajes áridos. Muchas especies de animales silvestres son atraídas por los abrevaderos, pero su conducta en los abrevaderos y los efectos de los abrevaderos en la fauna silvestre son, a menudo, poco conocidos. Grabé las tasas de consumo y de visitas de los tejones americanos (Taxidea taxus) en los abrevaderos que se encuentran al norte del Desierto de Chihuahua con cámaras automáticas durante un período de dos años. Los tejones visitaron los abrevaderos durante todo el año, pero principalmente durante la noche. Las visitas de los tejones tuvo un promedio de 1.87 visitas por sitio por semana y bebieron sólo en el $58 \%$ de esas visitas. La tasa de visitas y el número de episodios en los que bebieron agua por abrevadero por semana aumentó en verano que, además de tener temperaturas más altas, es la temporada reproductiva de los tejones.
\end{abstract}

Anthropogenic water sources such as tanks and ponds for livestock and troughs for wildlife (referred to hereafter as guzzlers) are ubiquitous features of arid landscapes. Rosenstock et al. (1999) reported that as of 1998 nearly 6000 guzzlers had been constructed for wildlife by game agencies in 11 western states. In addition, all livestock operations must provide anthropogenic water if natural water is not available. Many species of wildlife are attracted to water at guzzlers (Rosenstock et al. 1999). However, the impacts of the availability of anthropogenic water upon most species, including American badgers (Taxidea taxus), are poorly understood (Simpson et al. 2011).

American badgers are medium-sized carnivores and members of the family Mustelidae. They occur throughout the western and central United States, southern Canada, and northern Mexico (Lindzey 2003). Most studies of badgers were in the northern or coastal portions of their range, with reports from desert habitats limited to one brief description of diet, dens, and morphology (Lopez Soto 1980) and brief reports of observations at guzzlers (e.g., Rosenstock et al. 2004, Hall 2013). Badgers may occur in areas where no year-round surface water is available (Rosenstock et al. 2004). Water needs of badgers are not well studied. Jense (1968) reported that badgers held captive under moderate conditions remained in good condition without a source of water other than that contained in food, but in captivity badgers will drink water if available (Long and Killingley 1983). Only one previous study has reported details of water use by free-ranging badgers: Rosenstock et al. (2004) observed badgers drinking at water catchments in southwestern Arizona in the Sonoran Desert. Water may be a limiting factor in desert habitats.

Badgers are generally nocturnal, spending most of daytime in dens (Lindzey 2003). However, Goodrich (1994) is the only study that reported the hourly activity pattern. Goodrich's (1994) study was in southeastern Wyoming, an area which is wetter and colder than the Chihuahuan Desert. Badgers in hot deserts may show a different hourly activity pattern, perhaps with less activity during daytime. Furthermore,

1Department of Biology, University of New Mexico, Albuquerque, NM 87131. E-mail: rharison@unm.edu 
during winter in northern areas badgers may reduce their activity markedly, remaining in their dens for up to 70 days during periods of extreme cold or when prey are unavailable due to deep snow or frozen ground (Harlow 1981, Lindzey 2003). In southern areas badgers would not be expected to show such reduction of activity during winter, but detailed observations of annual activity patterns have not been reported for any area.

I used automatic cameras to determine how often badgers visited and drank from guzzlers. I then calculated the correlations of frequency of visitation and drinking with temperature and the annual pattern of anthropogenic water use in the Chihuahuan Desert. I used hourly and monthly rates of visitation to guzzlers to describe the daily and annual activity patterns of badgers as observed at these sites. This is the first study to report detailed observations of the behavior of American badgers in the Chihuahuan Desert and the first to report detailed observations of badger activity on an annual basis.

\section{STUdy AREA}

The study was conducted in the northern Chihuahuan Desert on the 142,000-ha Armendaris Ranch, a private bison (Bison bison) and hunting ranch in Sierra and Socorro Counties in south central New Mexico. Habitat within the study area was dominated by black grama grass (Bouteloua eriopoda) and shrubs creosotebush (Larrea tridentata), honey mesquite (Prosopis glandulosa), longleaf jointfir (Ephedra trifurca), sand sagebrush (Artemisia filifolia), and little-leaf sumac (Rhus microphyllum). Topography was flat or low rolling hills and elevations were 1300-1500 m. Annual precipitation falls mostly in summer and fall, and averaged $23.6 \mathrm{~cm}$ from 1951 to 2010 and 20.7 $\mathrm{cm}$ during fieldwork at Truth or Consequences, New Mexico (approximately $50 \mathrm{~km}$ from the study area; Western Regional Climate Center 2014). Average monthly minimum and maximum temperatures were $8.0^{\circ} \mathrm{C}$ and $23.7^{\circ} \mathrm{C}$, respectively, from 1951 to 2010 , and $9.0^{\circ} \mathrm{C}$ and $24.2{ }^{\circ} \mathrm{C}$ during fieldwork at Truth or Consequences, New Mexico. Guzzlers for a quail (Callipepla spp.) hunting program were located throughout the Armendaris Ranch along roads (Rollins et al. 2006). There were 62 guzzlers (1 guzzler per $4.5 \mathrm{~km}^{2}$ ) within the study area
$(28,000 \mathrm{ha})$. The average distance from one guzzler to the nearest guzzler was $0.81 \mathrm{~km}$ (SD $0.34 \mathrm{~km}$ ). Guzzlers consisted of 2000-L reservoirs accessed by $150 \times 20$-cm openings at ground level and filled via sheet metal rainfall collectors (Rollins et al. 2006; $N=59$ ) or concrete aprons $(N=3)$. There were no natural water sources within the study area other than ephemeral pools created by precipitation events.

\section{Methods}

I operated passively triggered automatic digital cameras (HC600 or PC900, Reconyx, Holmen, WI) at guzzlers from May 2012 through March 2014. The number of cameras deployed averaged 16.4 per week but varied from 5 to 21 per week due to demands of other projects. I divided the study area into northern and southern halves. Half of available cameras were deployed within each half of the study area. I operated available cameras at groups of adjacent guzzlers, observing continuously for 3 weeks before moving cameras to an adjacent group of guzzlers. When observations were completed at all guzzlers, cameras were moved to their initial locations, and the cycle was repeated. Overall, I averaged 20.9 weeks of observation per guzzler. Cameras were set to take bursts of 3 photographs when triggered, with a 1-s delay between bursts, and operated throughout the 24-h day. Cameras were visited weekly to retrieve photographs, change batteries, and be moved as needed.

For each guzzler, dates and times of badger visits and whether or not badgers drank were recorded. I recorded one drink regardless of how many times the badger actually drank during one visit. I assumed that a badger drank if it entered the guzzler reservoir far enough to reach the water or if water was seen dripping from the badger's mouth when it emerged. Visits by groups of badgers, such as mothers with young, were counted as one visit. To plot the daily hourly activity pattern, I combined all observations into hourly categories. To describe daily activity in relation to sunset and sunrise, I combined hourly observations into the following categories: midnight to sunrise (late night); sunrise to $2 \mathrm{~h}$ past sunrise (early morning); sunrise $+2 \mathrm{~h}$ to sunset $-2 \mathrm{~h}$ (daytime); $2 \mathrm{~h}$ before sunset to sunset (late afternoon); and sunset to midnight 


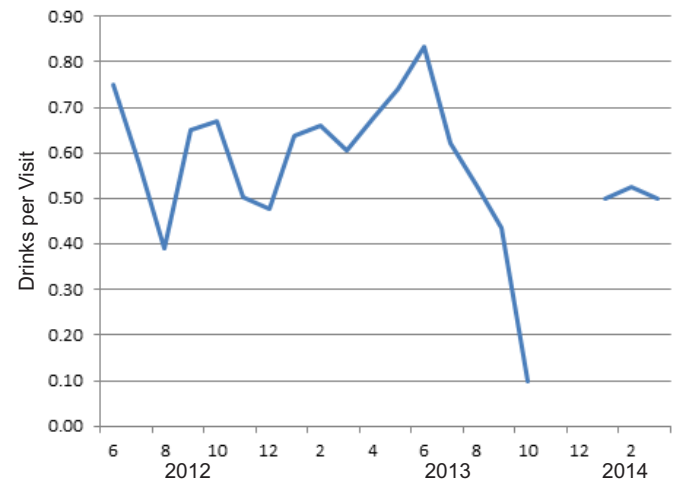

Fig. 1. Monthly average number of drinks per visit to guzzlers by badgers in the Chihuahuan Desert of southern New Mexico, 2012-2014.

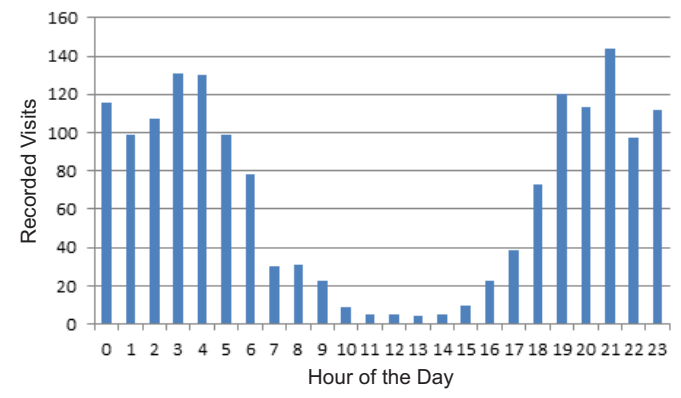

Fig. 2. Numbers of visits by hour of the day recorded for badgers at guzzlers in the Chihuahuan Desert of southern New Mexico, 2012-2014.

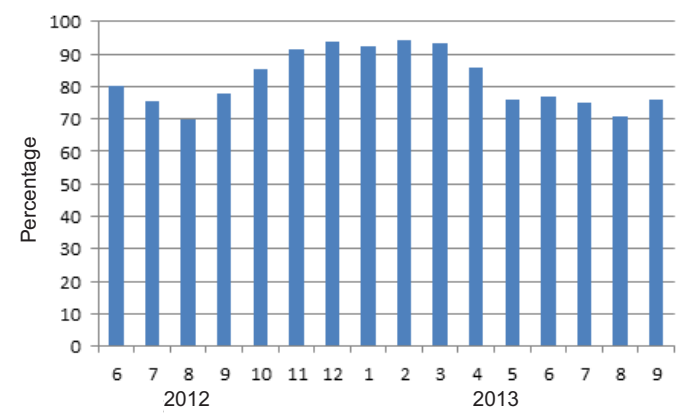

Fig. 3. Monthly percentages of visits between sunset and sunrise by badgers to guzzlers in the Chihuahuan Desert of southern New Mexico, 2012-2014.

(early night). I obtained times of sunrise and sunset from the United States Naval Observatory (2013). I averaged the number of visits per week per site over all guzzlers for each month and plotted the annual activity pattern. Relationships between temperature, visitation, and drinking were evaluated with Spearman's rank correlations. A simple linear correlation was used to examine the relationship between percentages of visits occurring during nighttime and numbers of hours of darkness.

\section{REsults}

Badgers visited guzzlers with cameras 2227 times during 1293 site-weeks of observation, and drank an average of 0.58 times per visit (95\% CI 0.53-0.64, Fig. 1). The average number of drinks per guzzler per week was 1.20 (95\% CI 1.00-1.39, range 0-13). Monthly average number of visits per guzzler was correlated with monthly average maximum temperature $\left(N=20\right.$ months, $r_{s}=0.492, P=$ $0.030)$. Monthly average number of drinks per guzzler was also correlated with monthly average maximum temperature $\left(N=20\right.$ months, $r_{s}$ $=0.530, P=0.017)$. Monthly average number of drinks per visit was correlated with monthly average number of visits $\left(N=20\right.$ months, $r_{s}=$ $0.700, P<0.001)$. Monthly average number of drinks per visit was not correlated with the average monthly maximum temperature $(N=$ 20 months, $\left.r_{s}=0.206, P=0.401\right)$.

Badgers visited guzzlers primarily at night (Fig. 2). Visits were distributed in relation to sunrise and sunset as follows: late night $42.9 \%$, early morning $6.2 \%$, daytime $7.1 \%$, late afternoon $5.6 \%$, and early night $38.2 \%$. The percentages of visits occurring each week between sunset and sunrise were highly correlated with the number of hours of darkness $(r=0.993$, $P<0.001, N=63$ ). Higher percentages of visits during nighttime occurred in winter than in summer (Fig. 3).

The average number of visits per site-week was 1.87 (95\% CI 1.58-2.16, range 0-17, median $1.0, N=80$ weeks) from May 2012 to March 2014 (Fig. 4). Badgers visited guzzlers during an average of $54.7 \%$ of an overall total of 1293 site-weeks, and $65.2 \%$ of 1055 site-weeks prior to a significant rain event in September 2013 (see below). At least one badger was photographed at guzzlers during $15.6 \%$ of cameranights or, equivalently, every 6.4 nights on average at each site. Badgers were photographed in the company of other badgers only during June, July, and August. During those months, badgers in groups comprised 10.5\% 


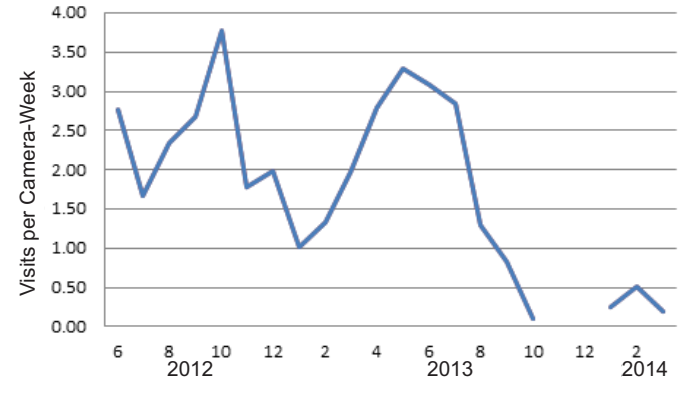

Fig. 4. Monthly average number of visits per cameraweek by badgers to guzzlers in the Chihuahuan Desert of southern New Mexico, 2012-2014.

of badgers seen. Groups of 2 and 3 badgers comprised $88.9 \%$ and $11.2 \%$ of group sightings, respectively.

\section{Discussion}

The number of drinking episodes per visit increased as the number of visits per week increased, and the number of visits per week increased with rising temperatures, which together resulted in the number of drinking episodes per guzzler per week increasing as temperatures rose. During summer the percentage of visits during which badgers drank appeared to increase (Fig. 1), but overall the number of drinks per visit did not correlate with temperatures. In a hotter study area in southwestern Arizona, Rosenstock et al. (2004) observed badgers drinking during $91 \%$ of visits, in comparison to $58 \%$ in this study, and bathing during $2 \%$ of visits, a behavior never observed in this study. The results of this study combined with those of Rosenstock et al. (2004) suggest that badgers increase their drinking in response to higher temperatures. However, in addition to temperature, breeding activity may affect drinking frequency. Summer is mating season for badgers (Lindzey 2003), and badger movements are greatest during the mating season (Paulson 2007, Quinn 2008). Whether in response to temperature or mating activity or both, during summer badgers in the study area increased their water consumption at guzzlers by visiting more often and by drinking more often when they visited.

Visitation declined immediately following a significant and destructive rain event in September 2013. Recorded rainfall that month was $15.75 \mathrm{~cm}$, the highest rainfall of any month on record since 1950 (Western Regional Climate Center 2014). An abundance of surface water is not likely the cause of the decline, as surface water disappeared within a few days of the event. It is unlikely that the badger population was reduced by drowning in burrows, as badgers will leave flooded burrows, even in the presence of humans (Lopez Soto 1980). The reason for this decline of visitation is not known.

Badgers visited guzzlers on the Armendaris Ranch throughout the year and on average 1-2 times per guzzler per week (Fig. 4). Similarly, Hall (2013) reported 0.7 badger visits per camera-week in the Mojave and Great Basin Deserts, and Rosenstock et al. (2004) reported 232 badger visits in 37,989 hours of video recording, or 1.02 visits per camera-week. The results of this study and those of Hall (2013) and Rosenstock et al. (2004) suggest that badgers do not visit guzzlers in desert areas very often even though anthropogenic water is available.

Given that the specific water needs of badgers are so poorly understood, it is possible only to speculate on the significance of anthropogenic water to badgers in deserts. In the study area, badgers drank from each guzzler at most only a few times per week. However, badgers drank at guzzlers throughout the year and increased their drinking in summer. Badgers may not need anthropogenic water to survive in deserts, but anthropogenic water may enable badgers to persist at higher densities than they would otherwise be found. Examination of water needs of captive badgers in relation to temperature, diet, and activity and of the distribution of badgers in desert areas with and without guzzlers would help clarify the situation.

As observed at guzzlers, badger activity was primarily crepuscular and nocturnal, with lowest activity during daytime, increased activity in the periods before sunset and after sunrise, and maximum activity during nighttime (Fig. 2). On average approximately $80 \%$ of visits occurred between sunset and sunrise. Longer hours of darkness in winter correlated with higher percentages of activity during nighttime (Fig. 3). Percentages of visits between sunrise and $2 \mathrm{~h}$ after sunrise, daytime, and between $2 \mathrm{~h}$ before sunset and sunset were comparable. These observations are consistent with the general conception of badgers as nocturnal carnivores (Lindzey 2003). Goodrich (1994) 
measured the activity of radioimplanted badgers in Wyoming and also reported that the badgers were least active during daytime, but on his study site there was more activity during daytime than on the Armendaris Ranch, perhaps due to temperature differences or prey behavior. There was no indication that badgers in the study area shifted activity to different times of the day or night to avoid seasonal temperature extremes.

A bimodal pattern of activity may have been present, with highest activity in early evening (19:00-21:00) and early morning (03:00-04:00) and slightly less activity in the middle of the night (Fig. 2). Activity observations presented by Goodrich (1994) were not sufficient to detect a bimodal pattern if one was present. A bimodal activity pattern would suggest coordination with peak activity of specific prey, such as found in bobcats whose primary prey are lagomorphs (Anderson and Lovallo 2003).

Badgers often visited guzzlers without drinking. In these cases they may have simply been moving through the area, or they may have visited guzzlers to obtain social information. Badgers frequently investigated sides of the water reservoir, apparently sniffing, and occasionally appeared to mark. All mustelids have anal scent glands, and olfactory signals on landscape features such as trails and vegetation are often involved in reproduction and territory definition (Long and Killingley 1983). However, the use of scent for social communication by American badgers has not been investigated. I speculate that, along with other landscape features such as trees and rocks, guzzlers may serve as sites for social communication, contributing to increased visitation with the approach and onset of the breeding season.

\section{ACKNOWLEDGMENTS}

I thank Mr. T. Turner and Mr. T. Waddell for permission to conduct the study on the Armendaris Ranch.

\section{Literature Cited}

Anderson, E.M., And M.J. Lovallo. 2003. Bobcat and lynx. Pages 758-786 in G.A. Feldhamer, B.C. Thompson, and J.A. Chapman, editors, Wild mammals of North America. 2nd edition. Johns Hopkins University Press, Baltimore, MD

GOODRICH, J.M. 1994. North American badgers (Taxidea taxus) and black-footed ferrets (Mustela nigripes): abundance, rarity, and conservation in a white-tailed prairie dog (Cynomys leucurus)-based community. Doctoral dissertation, University of Wyoming, Laramie, WY.

HaLL, L.K. 2013. The influence of anthropogenic development of water on coyotes and kit foxes in the Great Basin and Mojave Deserts. Master's thesis, Brigham Young University, Provo, UT.

HaRLOW, H.J. 1981. Torpor and other physiological adaptations of the badger (Taxidea taxus) to cold environments. Physiological Zoology 54:267-275.

JENSE, G.K. 1968. Food habits and energy utilization of badgers. Master's thesis, South Dakota State University, Brookings, SD.

Lindzey, F.G. 2003. Badger. Pages 683-691 in G.A. Feldhamer, B.C. Thompson, and J.A. Chapman, editors, Wild mammals of North America. 2nd edition. Johns Hopkins University Press, Baltimore, MD.

LONG, C.A., AND C.A. Killingley. 1983. The badgers of the world. Charles C. Thomas, Springfield, IL.

Lopez Soto, J.H. 1980. Datos ecologicos del Tlalcoyote Taxidea taxus berlandieri Baird (1858), en el Ejido Tokio Galeana, Nuevo Leon, Mexico. Master’s thesis, Universidad Autonoma de Nuevo Leon, Monterrey, Mexico. [In Spanish.]

Paulson, N.J. 2007. Spatial and habitat ecology of North American badgers (Taxidea taxus) in a native shrubsteppe ecosystem of eastern Washington. Master's thesis, Washington State University, Pullman, WA.

Quinn, J.H. 2008. The ecology of the American badger Taxidea taxus in California: assessing conservation needs on multiple scales. Doctoral dissertation, University of California, Davis, CA.

Rollins, D., B.D. Taylor, T.D. Sparks, T.E. Wadell, AND G. RiChaRDS. 2006. Species visitation at quail feeders and guzzlers in southern New Mexico. Pages 210-219 in S.B. Cederbaum, B.C. Faircloth, T.M. Terhune, J.J. Thompson, and J.P. Carroll, editors, Gamebird 2006: Quail VI and Perdix XII, 31 May-4 June 2006. Warnell School of Forestry and Natural Resources, Athens, GA.

Rosenstock, S.S., W.B. Ballakd, and J.C. Devos JR. 1999. Viewpoint: benefits and impacts of wildlife water developments. Journal of Range Management 52:302-311.

Rosenstock, S.S., M.J. Rabe, C.S. O'Brien, and R.B. WADDELL. 2004. Studies of wildlife water developments in southwestern Arizona: wildlife use, water quality, wildlife diseases, wildlife mortalities, and influences on native pollinators. Arizona Game and Fish Department, Research Branch Technical Guidance Bulletin No. 8, Phoenix, AZ.

Simpson, N.O., K.M. Stewart, and V.C. Bleich. 2011. What have we learned about water developments for wildlife? Not enough! California Fish and Game 97: 190-209.

United States Naval Observatory. 2013. Sun or moon rise/set table. [Accessed 8 April 2013]. http://aa.usno .navy.mil/cgi-bin/aa_rstablew.pl

Western Regional Climate Center. 2014. New Mexico climate summaries. [Accessed 30 April 2014]. http:// www.wrcc.dri.edu/summary/climsmnm.html

Received 8 June 2015

Accepted 4 November 2015 